\title{
Chemical and Biological Evaluation of Essential Oils from Cardamom Species
}

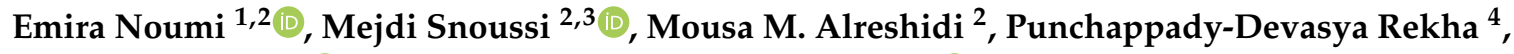 \\ Kanekar Saptami ${ }^{4}\left(\mathbb{D}\right.$, Lucia Caputo ${ }^{5}$, Laura De Martino ${ }^{5, * \mathbb{D}}$, Lucéia Fatima Souza ${ }^{5}$, \\ Kamel Msaada ${ }^{6}{ }^{D}$, Emilia Mancini ${ }^{5}$, Guido Flamini ${ }^{7}\left(D\right.$, Abdulbasit Al-sieni ${ }^{8}$ and \\ Vincenzo De Feo ${ }^{5}$ (D) \\ 1 Laboratory of Bioressources: Integrative Biology \& Recovery, High Institute of Biotechnology, \\ University of Monastir, Monastir 5000, Tunisia; emira_noumi@yahoo.fr \\ 2 Department of Biology, College of Science, University of Ha'il, Hai'1 2440, Saudi Arabia; \\ snmejdi@yahoo.fr (M.S.); mousa.algladi@gmail.com (M.M.A.) \\ 3 Laboratory of Genetics, Biodiversity and Valorisation of Bioresources, High Institute of Biotechnology, \\ University of Monastir 5000, Tunisia \\ 4 Yenepoya Research Centre, Yenepoya University, Mangalore 575018, India; rekhapd@hotmail.com (P.-D.R.); \\ kanekarsaptami@gmail.com (K.S.) \\ 5 Department of Pharmacy, University of Salerno, Via Giovanni Paolo II, 132, I-84084 Fisciano (Salerno), Italy; \\ luciaa.caputoo@gmail.com (L.C.); luceia.souza@ufrgs.br (L.F.S.); emancini@unisa.it (E.M.); \\ defeo@unisa.it (V.D.F.) \\ 6 Laboratory of Medicinal and Aromatic Plants, Biotechnology Center in Borj-Cedria Technopole, BP. 901, \\ Hammam-Lif 2050, Tunisia; msaada_kamel@hotmail.com \\ 7 Department of Pharmacy, University of Pisa, via Bonanno, 6, 56126 Pisa, Italy; guido.flamini@farm.unipi.it \\ 8 Department of Biochemistry, Faculty of Science, King Abdul Aziz University, Jeddah 21589, Saudi Arabia; \\ aalsieni@kau.edu.sa \\ * Correspondence: ldemartino@unisa.it; Tel.: +39-089-968-292; Fax: +39-089-969-602
}

Received: 28 September 2018; Accepted: 25 October 2018; Published: 30 October 2018

\begin{abstract}
To highlight the importance of the spices in the Mediterranean diet, the aim of the paper was to study the essential oil compositions and to clarify the potential differences in the biological activities of the three cardamom species. In the study, we compared the phytochemical profiles and biological activities of essential oils from Elettaria cardamomum, Aframomum corrorima and Amomum subulatum. The oils were analyzed using the GC and GC/MS techniques and were mainly constituted of the oxygenated monoterpenes which represents $71.4 \%, 63.0 \%$, and $51.0 \%$ of all compounds detected in E. cardamomum, A. corrorima and A. subulatum essential oils, respectively, 1,8-cineole was the main common compound between the tree tested volatile oil. The essential oils showed significant antimicrobial activity against Gram-positive and Gram-negative microorganisms tested especially the fungal strains. The Ethiopian cardamom was the most active essential oil with fungal growth inhibition zone ranging from 12.67 to $34.33 \mathrm{~mm}$, MICs values ranging from 0.048 to $0.19 \mathrm{mg} / \mathrm{mL}$, and MBCs values from 0.19 to $1.75 \mathrm{mg} / \mathrm{mL}$. The three tested essential oils and their main component (1,8-cineole) significantly increased the production of elastase and protease production, and motility in P. aeruginosa PAO1 in a dose dependent manner. In fact, at $10 \mathrm{mg} / \mathrm{mL}$ concentration, the three essential oils showed more than $50 \%$ of inhibition of elastolytic and proteolytic activities in P. aeruginosa PAO1. The same oils inhibited also the violacein production in $C$. violaceum strain. It was also noticed that at high concentrations, the $A$. corrorima essential oil significantly inhibited the germination of radish. A thorough knowledge of the biological and safety profiles of essential oils can produce applications of economic importance.
\end{abstract}

Keywords: green cardamom; Ethiopian cardamom; black cardamom; chemical composition; antimicrobial activity; allelopathic activity 


\section{Introduction}

Aromatic and medicinal plants offer a wide range of bioactive molecules used to contrary the spread of drug resistance pathogenic bacteria and fungi that cause severe and life-threatening infections [1,2]. Spices and aromatic plants are commonly used in Mediterranean regions in food preparation due to their antibacterial activities against several pathogenic Gram positive and Gram negative bacteria including: Listeria, Vibrio, Staphylococcus, Pseudomonas, Salmonella, Bacillus and Microccocus genera with multidrug resistance profiles [3,4]. The increasing of multi-resistance developed in most community, and hospital acquired pathogens can be attributed to the high use of antibiotics by consumers to feat pathogens. The scientific community developed since many years an interest in aromatic and medicinal plants with antimicrobial properties [1].

Essential oils are aromatic oily liquids with very complex nature known for their antimicrobial and medicinal properties [1]. Nowadays, some volatile oils and their mains components are used in food industry as antimicrobials due to their ability to control natural spoilage food process and to prevent growth of foodborne pathogens acting as food preservation and food safety molecules [3].

It is well known that both Gram positive and Gram negative pathogenic bacteria regulate their virulence traits using the quorum sensing (QS) system throughout the expression of a variety of genes as function of bacterial cell density [5]. For example, many virulence properties are regulated by the QS system including the synthesis of violacein in Chromobacterium violaceum ATCC 12472 [6,7], biofilm formation, swarming on semi-solid agar medium, production of elastase, protease and pyocyanin in the Pseudomonas aeruginosa PAO1 [8]. Several aromatic/medicinal essential oil and organic extract have been tested for their anti-QS activities [9,10]. A large variety of plant-derived molecules were described for their ability to interfere with the autoinducers molecules synthesized by Gram positive bacteria (AIP) and Gram negative bacteria (AHL) and attenuates the behavior of the QS-controlled virulence factors expression in both C. violaceum and P. aeruginosa PAO1 biomonitor strains [11,12].

The cardamom of commerce is called small green cardamom or the true cardamom (Elettaria cardamomum). There are many other plants belonging to the Amomum and Aframomum genera, both belonging to the cardamom family, producing aromatic seeds. Among them, clubbed together as false cardamoms, the most important and the one that is being grown commercially is Amomum subulatum. Most of these false cardamoms are used as flavoring plants and also as remedies for various ailments [13]. Elettaria cardamomum (L.) Maton is a tall, perennial, reed-like herb growing wild in rainforests of South India, Sri Lanka, and other tropical countries $[9,10]$. The plant is one of the world very ancient and expensive spices and is known as "the queen of spices" [14]. Amomum subulatum (A. Braun) P.C.M. Jensen, black cardamom or large cardamom [15], is native to Sikkim. The Sikkim State of India alone contributes 50\% of the world production of large cardamom [16]. Korarima (Aframomum corrorima (Braun) P.C.M. Jansen), also called Ethiopian cardamom or false cardamom, is native to Ethiopia but it is cultivated on a small scale in some West African countries. Korarima is a perennial, aromatic herb, and bearing flowers either terminally on aerial leaf shoots or from the ground level. Korarima is one of the aromatic medicinal plants used in traditional medicine by the people of southern Ethiopia [17-19].

Specifically, Eyob and colleagues [18] conducted an ethnobotanical survey in the southern regions of Ethiopia on the three major korarima growing wild including Gamo Gofa, Debub Omo and Kaffa. They identified 38 and 52 compounds, respectively in leaf and rhizome essential oils. The major component of the oil of the leaf was $\beta$-caryophyllene $(60.7 \%)$. The rhizome oil was dominated by $\gamma$-terpinene $(21.8 \%)$ and $\beta$-pinene $(17.6 \%)$.

It has been reported that in the chemical composition of different species of cardamoms, monoterpenes are the main compounds [14,17,20-22]. Also, antimicrobial activity of the cardamoms is reported [23,24]. On black cardamom, 1,8-cineole is the main component [15,25]. Eyob and co-workers $[17,18]$ reported the essential oil composition of Ethiopian cardamom. The presence of different structures of biomolecules in the volatile oils, allows a wider spectrum of bioactivity. 
Recently, it has been demonstrated that organic extracts from Amommum tsao-ko (Crevost et Lemarie) and Elettaria cardamomum exhibited anti-quorum sensing and antibiofilm activities [26,27].

The aims of this paper was to compare the different essential oil composition and to clarify the potential differences in the biological activities of the three tested species (including antimicrobial, allelopathic, and anti-quorum activities) as they are considered by plant sellers as the same "cardamom" species.

\section{Results}

\subsection{Essential Oil Composition}

Components of the essential oils, obtained by hydrodistillation and analyzed by gas chromatography-mass spectrometry (GC-MS) technique, are divided into five class compounds based on their chemical functional groups (Table 1).

Table 1. Essential oil composition (\%) of different species of cardamoms studied.

\begin{tabular}{|c|c|c|c|c|c|}
\hline \multirow{2}{*}{ Constituents } & \multirow{2}{*}{$\mathbf{K i}{ }^{*}$} & \multirow{2}{*}{$\mathbf{K i}^{* *}$} & \multicolumn{3}{|c|}{ Essential Oils (\%) } \\
\hline & & & E. cardamomum & A. corriroma & A. subulatum \\
\hline$\alpha$-thujene & 933 & 1035 & $0.1 \pm 0.00$ & $0.5 \pm 0.1$ & - \\
\hline$\alpha$-pinene & 941 & 1032 & $0.7 \pm 0.1$ & $1.4 \pm 0.2$ & $1.3 \pm 0.2$ \\
\hline sabinene & 977 & 1132 & $1.5 \pm 0.2$ & $1.2 \pm 0.2$ & - \\
\hline$\beta$-pinene & 982 & 1118 & $0.2 \pm 0.1$ & $4.6 \pm 0.3$ & $0.7 \pm 0.1$ \\
\hline 6-methyl-5-hepten-2-one & 987 & 1319 & - & $\begin{array}{c}-0.0 \\
-\end{array}$ & $0.2 \pm 0.1$ \\
\hline myrcene & 993 & 1174 & $1.2 \pm 0.1$ & $0.2 \pm 0.1$ & $0.4 \pm 0.1$ \\
\hline$\alpha$-phellandrene & 1006 & 1176 & - & $0.1 \pm 0.0$ & $1.6 \pm 0.1$ \\
\hline$\alpha$-terpinene & 1020 & 1188 & - & $0.4 \pm 0.1$ & - \\
\hline p-cymene & 1028 & 1280 & $1.1 \pm 0.2$ & $4.5 \pm 0.3$ & $2.6 \pm 0.3$ \\
\hline limonene & 1032 & 1203 & $2.5 \pm 0.2$ & $5.4 \pm 0.4$ & $2.4 \pm 0.5$ \\
\hline 1.8-cineole & 1034 & 1213 & $55.4 \pm 1.5$ & $51.8 \pm 1.3$ & $41.7 \pm 1.6$ \\
\hline$\gamma$-terpinene & 1063 & 1255 & $0.1 \pm 0.1$ & $0.9 \pm 0.1$ & $0.3 \pm 0.1$ \\
\hline cis-sabinene hydrate & 1070 & 1556 & - & $0.1 \pm 0.1$ & - \\
\hline $\begin{array}{l}\text { cis-linalool oxide } \\
\text { (furanoid) }\end{array}$ & 1076 & 1450 & $0.1 \pm 0.0$ & - & - \\
\hline terpinolene & 1090 & 1265 & $0.2 \pm 0.1$ & $0.4 \pm 0.1$ & - \\
\hline 2-hexyl furan & 1094 & & - & - & $0.3 \pm 0.1$ \\
\hline linalool & 1101 & 1553 & $0.9 \pm 0.1$ & $0.6 \pm 0.1$ & $3.0 \pm 0.2$ \\
\hline cis-p-menth-2-en-1-ol & 1123 & 1230 & $0.1 \pm 0.0$ & $0.3 \pm 0.1$ & - \\
\hline trans- $p$-menth-2-en-1-ol & 1142 & & - & $0.4 \pm 0.1$ & - \\
\hline sabina ketone & 1158 & 1652 & - & $0.1 \pm 0$ & - \\
\hline$\delta$-terpineol & 1172 & & - & $0.2 \pm 0.0$ & $0.6 \pm 0.1$ \\
\hline 4-terpineol & 1179 & 1611 & $3.3 \pm 0.3$ & $10.4 \pm 0.8$ & $1.7 \pm 0.2$ \\
\hline$p$-cymen-8-ol & 1185 & 1864 & - & $0.1 \pm 0.1$ & - \\
\hline$\alpha$-terpineol & 1191 & 1706 & $3.1 \pm 0.3$ & $4.9 \pm 0.5$ & $5.4 \pm 0.4$ \\
\hline trans-piperitol & 1206 & & - & $0.1 \pm 0.1$ & - \\
\hline neral & 1242 & 1656 & - & - & $0.9 \pm 0.2$ \\
\hline carvone & 1244 & 1752 & - & $0.2 \pm 0.1$ & - \\
\hline geraniol & 1256 & 1857 & - & $1.9 \pm 0.3$ & $12.5 \pm 0.8$ \\
\hline linalyl acetate & 1259 & 1565 & $0.4 \pm 0.1$ & - & - \\
\hline (E)-2-decenal & 1263 & & - & - & $0.7 \pm 0.1$ \\
\hline geranial & 1271 & 1267 & - & $0.2 \pm 0.0$ & $3.1 \pm 0.1$ \\
\hline 2-phenyl-2-butenal & 1285 & & - & - & $2.9 \pm 0.1$ \\
\hline Thymol & 1292 & 2198 & - & - & $0.3 \pm 0.1$ \\
\hline cis-2.3-pinanediol & 1315 & & - & - & $0.7 \pm 0.1$ \\
\hline methyl geranate & 1325 & & $0.2 \pm 0.0$ & - & - \\
\hline myrtenyl acetate & 1327 & 1698 & - & $0.1 \pm 0.0$ & - \\
\hline $\begin{array}{l}\text { exo-2-hydroxycineol } \\
\text { acetate }\end{array}$ & 1345 & & - & $0.3 \pm 0.1$ & - \\
\hline$\alpha$-terpinyl acetate & 1352 & 1709 & $28.6 \pm 1.1$ & $3.6 \pm 0.5$ & - \\
\hline$\alpha$-copaene & 1377 & 1497 & - & $0.1 \pm 0.0$ & - \\
\hline geranyl acetate & 1385 & 1765 & $0.2 \pm 0.1$ & $1.2 \pm 0.3$ & $6.0 \pm 0.7$ \\
\hline
\end{tabular}


Table 1. Cont.

\begin{tabular}{|c|c|c|c|c|c|}
\hline \multirow{2}{*}{ Constituents } & \multirow{2}{*}{$\mathbf{K i}^{*}$} & \multirow{2}{*}{$\mathbf{K i} \mathbf{i}^{* *}$} & \multicolumn{3}{|c|}{ Essential Oils (\%) } \\
\hline & & & E. cardamomum & A. corriroma & A. subulatum \\
\hline (E)-2-decenyl acetate & 1407 & & - & - & $1.1 \pm 0.1$ \\
\hline$\beta$-caryophyllene & 1419 & 1612 & - & $0.4 \pm 0.1$ & \\
\hline$\gamma$-muurolene & 1478 & 1704 & - & - & $0.3 \pm 0.1$ \\
\hline$\delta$-cadinene & 1524 & 1773 & - & - & $0.3 \pm 0.1$ \\
\hline elemol & 1550 & & - & - & $0.2 \pm 0.0$ \\
\hline (E)-nerolidol & 1565 & 2050 & - & $1.3 \pm 0.2$ & $1.1 \pm 0.1$ \\
\hline caryophyllene oxide & 1582 & 2008 & - & $0.3 \pm 0.1$ & - \\
\hline $\begin{array}{l}\text { Oxygenated } \\
\text { monoterpenes }\end{array}$ & & & $63.0 \pm 0.3$ & $71.4 \pm 0.3$ & $51.0 \pm 0.4$ \\
\hline $\begin{array}{l}\text { Monoterpene } \\
\text { hydrocarbons }\end{array}$ & & & $36.9 \pm 0.2$ & $24.7 \pm 0.2$ & $34.2 \pm 0.3$ \\
\hline $\begin{array}{l}\text { Sesquiterpene } \\
\text { hydrocarbons }\end{array}$ & & & 0.0 & $0.5 \pm 0.1$ & $0.6 \pm 0.1$ \\
\hline $\begin{array}{l}\text { Oxygenated } \\
\text { sesquiterpenes }\end{array}$ & & & 0.0 & $1.6 \pm 0.2$ & $1.3 \pm 0.1$ \\
\hline Others & & & 0.0 & 0.0 & $5.2 \pm 0.1$ \\
\hline Total identified & & & 99.9 & 98.2 & 92.3 \\
\hline
\end{tabular}

${ }^{*}$ Kovats retention index determined relative to the tR of a series of $n$-alkanes $\left(C_{10}-C_{35}\right)$ on a HP-5 MS column;

${ }^{* *}$ Kovats retention index determined relative to the tR of a series of $n$-alkanes $\left(C_{10}-C_{35}\right)$ on HP Innowax.

The major class compounds were the oxygenated monoterpenes which represents $71.4 \%, 63.0 \%$, and $51.0 \%$ of all compounds detected in E. cardamomum, A. corrorima and A. subulatum essential oils, respectively. This family is dominated by 1,8-cineole where its maximum percentage was observed in the green cardamom (55.4\%), followed by the Ethiopian cardamom (51.8) and the black cardamom (41.7).

The monoterpene hydrocarbonss were the second dominant components in the three cardamom varieties and represent $36.9 \%$ in the green cardamom essential oil, followed respectively by the black cardamom (34.2\%) and the Ethiopian cardamom (24.7\%). The second class of components is dominated by $\alpha$-terpinyl acetate $(28.6 \%)$ in green cardamom essential oil, 4 -terpineol for the Ethiopian cardamom $(10.4 \%)$, and geraniol (12.5\%) in the essential oil of black cardamom.

The sesquiterpenes hydrocarbons were found only in the essential oil of the A. corriroma and $A$. subulatum representing $(0.5 \%)$ and $(0.6 \%)$ of the total compounds identified, respectively. The oxygenated sesquiterpenes were also found in the black and Ethiopian cardamom essential oils representing $1.6 \%$ and $1.3 \%$ of the total compounds identified, respectively.

The principal component analysis (PCA) was carried out in order to determine the relationship between the three cardamom varieties on the basis of their essential oil composition. A better discrimination was revealed on the three dimensional visualization of the plotted scores. Results obtained from the PCA showed the existence of three well-defined groups clearly distinguished both in quality and in quantity (Figure 1A).

These results confirm that, despite the presence of the 1,8-cineole as a main component in the three essential oils, they are both qualitatively and quantitatively chemically different. Results obtained from the cluster analysis (Figure 1B) confirmed the existence of one well-defined group represented by the black and Ethiopian cardamom oils suggesting similar compositions. The green cardamom essential oil was clearly distinguished from the latter group both in quality and in quantity. 

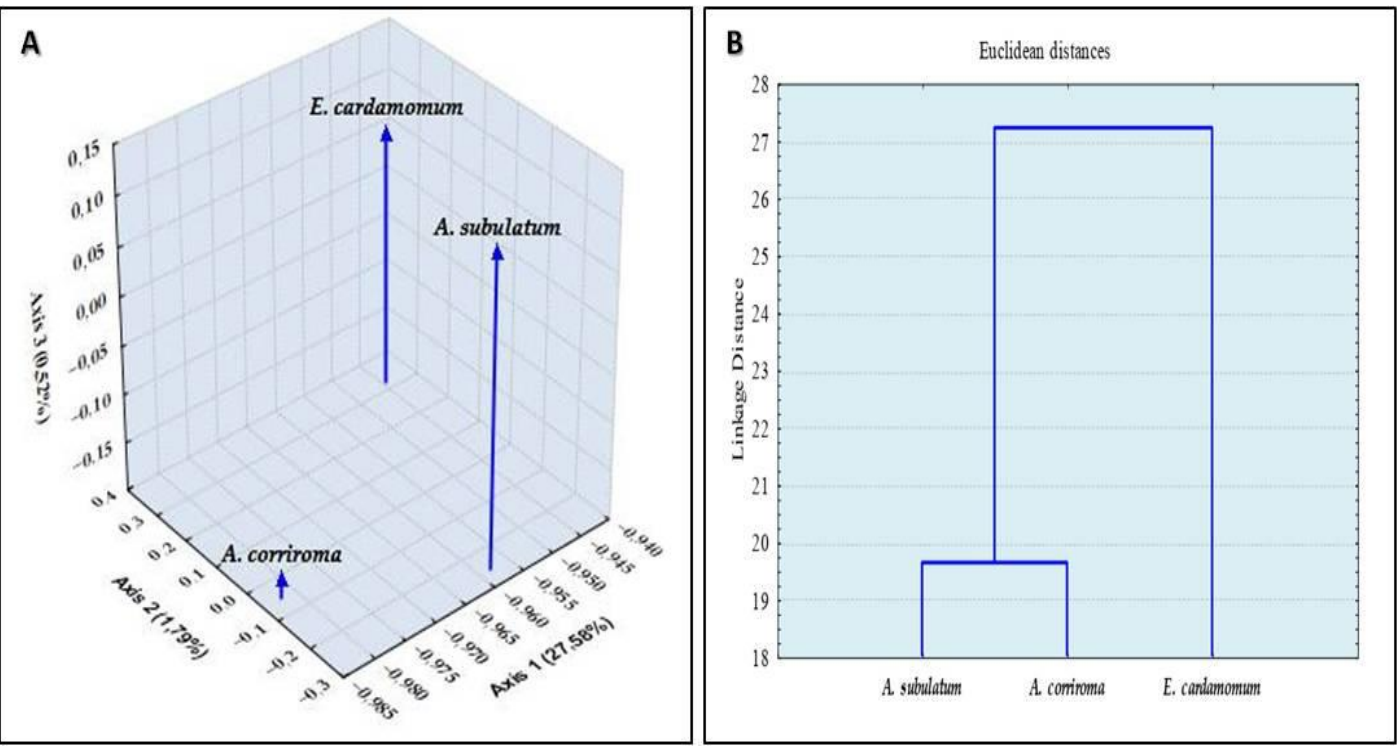

Figure 1. (A) Relative positions of the three essential oils tested based on their phytochemical composition in the space defined by the three principal components. (B) Cluster analysis obtained in the cluster analysis of the essential oils of green cardamom, Ethiopian cardamom, and black cardamom based on the data (Table 1): horizontal, samples analyzed; vertical, differentiation level between the three essential oils tested.

\subsection{Antimicrobial Activities}

The antibacterial activity of the three essential oils was tested using the disc diffusion assay and using the microdilution assay on twenty five Gram-positive and Gram-negative bacteria including those frequently associated with food contamination and human disorders. The results were recorded as the diameters $(\mathrm{mm})$ of the growth inhibition zone and as a minimal inhibition and bactericidal concentrations $(\mathrm{mg} / \mathrm{mL})$ (Tables 2 and 3$)$.

For the antifungal activity (Table 2), the results showed that the three essential oils were also active against the yeast strains tested with high diameters of fungal growth inhibition zone ranging from 14.33 to $21.67 \mathrm{~mm}$ for the green cardamom oil, from 12.67 to $34.33 \mathrm{~mm}$ for the Ethiopian cardamom oil, and from 6.0 to $40.33 \mathrm{~mm}$ for the black cardamom oil. The Ethiopian cardamom was the most active essential oil with MICs values ranging from 0.048 to $0.19 \mathrm{mg} / \mathrm{mL}$, and MBCs values from 0.19 to $1.75 \mathrm{mg} / \mathrm{mL}$. Using the Duncan's test comparing the mean diameters of the microbial growth inhibition zones, independently of the microorganism tested, Corriroma essential oil was classified as the most active oil (mean diameter $17.75 \mathrm{~mm}$ ) followed by the green cardamom oil (mean diameter $16.27 \mathrm{~mm}$ ) and finally the Ethiopian cardamom oil (mean diameter $16.21 \mathrm{~mm}$ ).

The essential oils showed significant antimicrobial activity against all Gram-positive and Gram-negative microorganisms tested, giving inhibition zones ranging between 6 and $41.33 \mathrm{~mm}$ for the green cardamom essential oil, between 11.33 and $32.00 \mathrm{~mm}$ for the Ethiopian cardamom essential oil, and between 6 to $43 \mathrm{~mm}$ for the black cardamom essential oil. The high diameters of the growth inhibition zones were obtained when Gram-positive bacteria are tested for the three volatile oils. 
Table 2. Antifungal activity of cardamom essential oils as compared to the drug agent (Amphotericin B) as determined by the disc diffusion and microdilution assays.

\begin{tabular}{|c|c|c|c|c|c|c|c|c|c|c|}
\hline \multirow[b]{2}{*}{ Microorganisms } & \multicolumn{3}{|c|}{ Green cardamom } & \multicolumn{3}{|c|}{ Ethiopian cardamom } & \multicolumn{3}{|c|}{ Black cardamom } & \multirow{2}{*}{$\begin{array}{c}\text { Amphotericin B } \\
(10 \mathrm{mg} / \mathrm{mL})\end{array}$} \\
\hline & $\mathrm{ZI}^{*} \pm \mathrm{SD}^{* *}$ & MIC *** & MFC $^{* * * *}$ & $\mathbf{Z I}^{*} \pm \mathbf{S D}^{* *}$ & MIC *** & MFC **** & $\mathrm{ZI} \pm \mathrm{SD}$ & MIC & MFC & \\
\hline Candida tropicalis $06-085$ & $15.33 \pm 0.57^{\mathrm{i}}$ & 0.048 & 6.25 & $34.33 \pm 0.57^{\mathrm{a}}$ & 0.048 & 0.19 & $6.00 \pm 0.00^{1}$ & 0.048 & 3.125 & - \\
\hline Candida parapsilosis ATCC 22019 & $21.67 \pm 0.57^{\mathrm{cd}}$ & 0.048 & 6.25 & $24.33 \pm 0.57^{\mathrm{f}}$ & 0.19 & 0.78 & $6.00 \pm 0.00^{1}$ & 0.097 & 6.25 & $10.33 \pm 0.57$ \\
\hline Candida krusei ATCC 6258 & $14.33 \pm 0.57^{\mathrm{ij}}$ & 0.048 & 12.5 & $15.33 \pm 0.57 \mathrm{jkl}$ & 0.097 & 1.75 & $6.00 \pm 0.00^{1}$ & 0.048 & 6.25 & $12.00 \pm 0.00$ \\
\hline Candida glabrata ATCC 900030 & $16.33 \pm 0.57 \mathrm{~h}$ & 0.097 & 12.5 & $31.00 \pm 1.00^{b c}$ & 0.097 & 078 & $40.33 \pm 0.57^{b}$ & 0.048 & 6.25 & $14.33 \pm 0.57$ \\
\hline Candida guilliermondi 06-018 & $16.67 \pm 0.57$ gh & 0.048 & 6.25 & $30.33 \pm 0.57^{\mathrm{cd}}$ & 0.097 & 0.78 & $41.00 \pm 0.00^{\mathrm{b}}$ & 0.097 & 3.125 & - \\
\hline Candida albicans ATCC 2019 & $15.33 \pm 0.57^{\mathrm{i}}$ & 0.097 & 6.25 & $12.67 \pm 0.57^{\text {nop }}$ & 0.097 & 0.39 & $12.00 \pm 0.00^{\mathrm{h}}$ & 0.048 & 3.125 & $14.66 \pm 0.57$ \\
\hline Saccharomyces cerevisiae 11-161 & $18.67 \pm 0.57^{\mathrm{f}}$ & 0.097 & 6.25 & $21.67 \pm 0.57 \mathrm{~g}$ & 0.097 & 0.39 & $40.33 \pm 0.57^{b}$ & 0.048 & 6.25 & - \\
\hline
\end{tabular}
*ZI: Inhibition zone in diameter $(\mathrm{mm} \pm \mathrm{SD})$ around the discs impregnated with $10 \mathrm{mg} /$ disk of essential oil including disc diameter. ${ }^{* *} \mathrm{SD}:$ standard deviation; (a-q): Means followed by
the same letters are not significantly different at $p=0.05$ based on Duncan's multiple range tests. ${ }^{* * *}$ MIC: Minimum Inhibitory Concentration (mg/mL). ${ }^{* * *}$ MFC: Minimum Fungicidal Concentration $(\mathrm{mg} / \mathrm{mL})$. 
Table 3. Antibacterial activity of cardamom essential oils as compared to the drug agent (Ampicillin) determined by the disc diffusion and microdilution assays.

\begin{tabular}{|c|c|c|c|c|c|c|c|c|c|c|}
\hline \multirow[b]{2}{*}{ Microorganisms } & \multicolumn{3}{|c|}{ Green cardamom } & \multicolumn{3}{|c|}{ Ethiopian cardamom } & \multicolumn{3}{|c|}{ Black cardamom } & \multirow{2}{*}{$\begin{array}{l}\text { Ampicillin } \\
(10 \mathrm{mg} / \mathrm{mL})\end{array}$} \\
\hline & $\mathrm{ZI}^{*} \pm \mathrm{SD}^{* *}$ & MIC *** & $\mathrm{MBC} * * * *$ & $\mathrm{ZI}^{*} \pm \mathrm{SD}^{* *}$ & MIC *** & $\mathrm{MBC} * * * *$ & $\mathrm{ZI} * \pm \mathrm{SD}^{* *}$ & MIC *** & $\mathrm{MBC} * * * *$ & \\
\hline Aerococcus viridans & $20.33 \pm 0.57^{\mathrm{e}}$ & 0.048 & 6.25 & $25.67 \pm 0.57^{\mathrm{e}}$ & 0.048 & 0.39 & $35.00 \pm 0.00^{c}$ & 0.048 & 3.125 & $14.67 \pm 0.57$ \\
\hline Bacillus cereus & $11.67 \pm 0.57^{\mathrm{n}}$ & 0.048 & 6.25 & $16.33 \pm 0.57^{\mathrm{ij}}$ & 0.048 & 3.125 & $35.67 \pm 0.57^{\mathrm{c}}$ & 0.048 & 1.56 & - \\
\hline Bacillus subtilis ATCC 6633 & $12.67 \pm 0.57 \mathrm{klmn}$ & 0.048 & 12.5 & $14.67 \pm 0.57 \mathrm{klm}$ & 0.048 & 3.125 & $7.00 \pm 0.00 \mathrm{k}$ & 0.048 & 0.78 & $11.33 \pm 0.57$ \\
\hline Listeria monocytogenes ATCC 19115 & $17.33 \pm 0.57 \mathrm{~g}$ & 0.048 & 12.5 & $14.33 \pm 0.57 \mathrm{~lm}$ & 0.19 & 6.25 & $6.00 \pm 0.00^{1}$ & 0.048 & 1.56 & - \\
\hline Micrococcus luteus NCIMB 8166 & $41.33 \pm 1.15^{\mathrm{a}}$ & 0.048 & 6.25 & $29.33 \pm 0.57^{\mathrm{d}}$ & 0.048 & 6.25 & $7.67 \pm 0.57^{\mathrm{jk}}$ & 0.048 & 3.125 & $30.33 \pm 0.57$ \\
\hline Staphylococcus aureus MR (B2) & $13.67 \pm 0.57 \mathrm{jk}$ & 0.048 & 12.5 & $17.00 \pm 1.00^{\mathrm{i}}$ & 0.048 & 12.5 & $6.00 \pm 0.00^{1}$ & 0.048 & 6.25 & $16.33 \pm 0.57$ \\
\hline Staphylococcus aureus ATCC 6816 & $32.67 \pm 0.57 \mathrm{~b}$ & 0.048 & 6.25 & $32.00 \pm 0.00^{\mathrm{b}}$ & 0.097 & 12.5 & $19.67 \pm 0.57^{\mathrm{f}}$ & 0.048 & 3.125 & $24.33 \pm 0.57$ \\
\hline Staphylococcus epidermidis ATCC 12228 & $11.67 \pm 0.57^{\mathrm{n}}$ & 0.048 & 6.25 & $13.67 \pm 0.57 \mathrm{mn}$ & 0.097 & 6.25 & $43.00 \pm 1.00^{\mathrm{a}}$ & 0.097 & 1.56 & $12.33 \pm 0.57$ \\
\hline Escherichia coli ATCC 25922 & $15.33 \pm 0.57^{\mathrm{i}}$ & 0.048 & 12.5 & $15.33 \pm 0.57^{\mathrm{jkl}}$ & 0.048 & 12.5 & $6.00 \pm 0.00^{1}$ & 0.048 & 0.78 & $11.67 \pm 0.57$ \\
\hline Klebsiella pneumoniae & $10.33 \pm 0.57^{\circ}$ & 0.048 & 12.5 & $12.00 \pm 0.00 \mathrm{opq}$ & 0.097 & 3.125 & $8.33 \pm 0.57^{i}$ & 0.097 & 6.25 & $17.33 \pm 0.57$ \\
\hline Pseudomonas aeruginosa ATCC 27853 & $6.00 \pm 0.00^{r}$ & 0.048 & 12.5 & $11.33 \pm 0.57 \mathrm{q}$ & 0.048 & 3.125 & $10.33 \pm 0.57^{\mathrm{i}}$ & 0.048 & 3.125 & $22.67 \pm 0.57$ \\
\hline Proteus mirabils & $8.00 \pm 0.00^{P}$ & 0.048 & 25 & $11.67 \pm 0.57 \mathrm{pq}$ & 0.048 & 6.25 & $13.67 \pm 0.57^{\mathrm{g}}$ & 0.048 & 12.5 & $25.67 \pm 0.57$ \\
\hline Shewanella putrefaciens & $13.00 \pm 0.00 \mathrm{klm}$ & 0.097 & 12.5 & $15.33 \pm 0.57^{\mathrm{jkl}}$ & 0.19 & 6.25 & $30.33 \pm 0.57^{\mathrm{d}}$ & 0.048 & 3.125 & $7.00 \pm 0.00$ \\
\hline Salmonella typhimirium ATCC 14028 & $10.00 \pm 0.00^{\circ}$ & 0.048 & 12.5 & $9.33 \pm 0.57^{\mathrm{r}}$ & 0.048 & 3.125 & $7.67 \pm 0.57^{\mathrm{jk}}$ & 0.048 & 0.78 & $17.67 \pm 1.15$ \\
\hline Shigella flexenerii ATCC 12022 & $22.33 \pm 0.57^{\mathrm{c}}$ & 0.048 & 6.25 & $19.67 \pm 0.57 \mathrm{~h}$ & 0.048 & 6.25 & $14.33 \pm 0.57 \mathrm{~g}$ & 0.048 & 0.39 & $10.67 \pm 0.57$ \\
\hline Vibrio alginolyticus ATCC 17749 & $20.67 \pm 0.57$ de & 0.048 & 3.125 & $16.33 \pm 0.57^{\mathrm{ij}}$ & 0.097 & 25 & $7.00 \pm 0.00 \mathrm{k}$ & 0.048 & 1.56 & - \\
\hline Vibrio alginolyticus ATCC 33787 & $12.33 \pm 0.57 \operatorname{lmn}$ & 0.048 & 12.5 & $15.33 \pm 0.57 \mathrm{jkl}$ & 0.097 & 25 & $26.67 \pm 0.57^{\mathrm{e}}$ & 0.048 & 6.25 & $13.33 \pm 0.57$ \\
\hline Vibrio cholerae ATCC 9459 & $7.00 \pm 0.00 q$ & 0.097 & 12.5 & $14.33 \pm 0.57 \mathrm{~lm}$ & 0.048 & 25 & $6.00 \pm 0.00^{1}$ & 0.048 & 12.5 & $7.00 \pm 0.00$ \\
\hline Vibrio parahaemolyticus ATCC 17802 & $20.67 \pm 0.57$ de & 0.097 & 12.5 & $14.33 \pm 0.57^{\mathrm{lm}}$ & 0.048 & 12.5 & $7.00 \pm 0.00^{\mathrm{k}}$ & 0.048 & 1.56 & $13.33 \pm 0.57$ \\
\hline Vibrio vulnificus ATCC 27562 & $13.00 \pm 0.00^{\mathrm{klm}}$ & 0.048 & 12.5 & $15.67 \pm 0.57^{\mathrm{jk}}$ & 0.097 & 12.5 & $29.67 \pm 0.57^{d}$ & 0.097 & 6.25 & $30.33 \pm 0.57$ \\
\hline Vibrio vulnificus ATCC 33149 & $13.33 \pm 0.57^{\circ}$ & 0.048 & 12.5 & $13.00 \pm 1.00^{\text {no }}$ & 0.048 & 6.25 & $6.00 \pm 0.00^{1}$ & 0.048 & 6.25 & $12.33 \pm 0.57$ \\
\hline Serratia marcescens & $14.33 \pm 0.57 \mathrm{ij}$ & 0.048 & 12.5 & $12.33 \pm 0.57 \mathrm{opq}$ & 0.048 & 3.125 & $8.33 \pm 0.57^{i}$ & 0.048 & 3.125 & $13.67 \pm 0.57$ \\
\hline
\end{tabular}

* ZI: Inhibition zone in diameter $(\mathrm{mm}+\mathrm{SD})$ around the discs impregnated with $10 \mathrm{mg} /$ disk of essential oil including disc diameter. ** SD: standard deviation; (a-q): Means followed by the same letters are not significantly different at $p=0.05$ based on Duncan's multiple range tests. ${ }^{* * *}$ MIC: Minimum Inhibitory Concentration (mg $\left./ \mathrm{mL}\right) . * * * *$ MBC: Minimum Bactericidal Concentration $(\mathrm{mg} / \mathrm{mL})$. 
Indeed, the highest activity was observed on S. epidermidis ATCC 12228 (diameter $43.00 \mathrm{~mm}$ ) for the black cardamom essential oil, on M. luteus NCIMB 8166 (diameter $41.33 \mathrm{~mm}$ ) for the green cardamom essential oil, and on S. aureus ATCC 6816 (diameter $32.00 \mathrm{~mm}$ ) for the Ethiopian cardamom oil.

Using the microdilution assay, the results showed that weak concentrations of the three essential oils tested were sufficient to inhibit the growth of all microorganisms tested (MICs values), and to completely stop the bacterial growth (MBCs values). In fact, the lowest MICs values were ranged from 0.048 to $0.19 \mathrm{mg} / \mathrm{mL}$ for Ethiopian cardamom oil, and from 0.048 to $0.097 \mathrm{mg} / \mathrm{mL}$ for the green and black cardamom oils. Concentrations as low as $0.39 \mathrm{mg} / \mathrm{mL}$ was sufficient to reproduce a bacteriostatic effect for the black Ethiopian cardamom oil, $0.78 \mathrm{mg} / \mathrm{mL}$ for the black cardamom oil, and $6.25 \mathrm{mg} / \mathrm{mL}$ for the green cardamom oil (Table 3).

The results of the effects of the three essential oils and their main component 1,8-cineole on virulence factors production in P. aeruginosa PAO1 showed an inhibition of the motility in a concentration dependent manner (Table 4).

Table 4. Effect of the three essential oils tested and 1,8-cineole at different concentrations (on swarming motility in PAO1 tested on LB semisolid medium.

\begin{tabular}{ccccc}
\hline \multirow{2}{*}{$\begin{array}{c}\text { Concentration } \\
(\mu \mathrm{g} / \mathrm{mL})\end{array}$} & \multicolumn{3}{c}{ Essential Oils } & $\begin{array}{c}\text { Main Component } \\
\text { 1,8-Cineole }\end{array}$ \\
\cline { 2 - 4 } & Green cardamom & Black cardamom & Ethiopian cardamom & \\
\cline { 2 - 4 } & $\mathbf{M} \pm \mathbf{S D}{ }^{*}$ & $\mathbf{M} \pm \mathbf{S D}{ }^{*}$ & $\mathbf{M} \pm \mathbf{S D}{ }^{*}$ & $\mathbf{M}^{*} \mathbf{S D}^{*}$ \\
\hline Control & $54.00 \pm 1.00$ & $54.00 \pm 1.00$ & $54.00 \pm 1.00$ & $54.00 \pm 1.00$ \\
10 & $22.00 \pm 1.00$ & $52.33 \pm 0.58$ & $53.76 \pm 0.58$ & $17.33 \pm 1.15$ \\
50 & $17.67 \pm 0.58$ & $50.67 \pm 1.15$ & $53.00 \pm 0.00$ & $15.00 \pm 0.00$ \\
100 & $13.67 \pm 0.58$ & $46.76 \pm 1.15$ & $32.67 \pm 0.58$ & $13.67 \pm 0.58$ \\
200 & $11.13 \pm 1.00$ & $35.76 \pm 0.58$ & $13.33 \pm 1.15$ & $12.33 \pm 0.58$ \\
400 & $8.33 \pm 0.58$ & $33.00 \pm 2.65$ & $8.33 \pm 0.58$ & $10.33 \pm 0.58$ \\
\hline
\end{tabular}

${ }^{*} \mathrm{M} \pm \mathrm{SD}$ : Mean diameter expressed in $\mathrm{mm} \pm$ standard deviation.

Under control conditions, PAO1 strain give a diameter about $54 \mathrm{~mm}$ and in the presence of different concentrations of the three essential oils and their main component (1,8-cineole), the bacteria were able to grow and form a colony in the center with diameter not exceeding $8.33 \mathrm{~mm}$. In fact, the highest level of inhibition in the migration of PAO1 was recorded with the green and ethiopian volatile oils at $400 \mu \mathrm{g} / \mathrm{mL}$. The diameter of the colony ranged from $54 \pm 1 \mathrm{~mm}$ to $8.33 \pm 0.58$. 1,8-Cineole was also able to inhibit the swarming ability of the PAO1 strain with a diameter ranging from $17.33 \pm 1.15 \mathrm{~mm}$ at $10 \mu \mathrm{g} / \mathrm{mL}$ to $10.33 \pm 0.58 \mathrm{~mm}$ at $400 \mu \mathrm{g} / \mathrm{mL}$.

The tested essential oils and their main component (1,8-cineole) decreased the production of the QS-controlled virulence factors (elastase and protease) in P. aeruginosa PAO1 in a concentration dependant manner. At $10 \mu \mathrm{g} / \mathrm{mL}$ concentration, the three essential oils showed more than $50 \%$ of inhibition of elastolytic and proteolytic activities in P. aeruginosa PAO1 (Figure 2A,B).

The three tested essential oils and their main component (1,8-cineole) exhibited anti-QS activity against $C$. violaceum 026 starter strain. After $24 \mathrm{~h}$ incubation, the weakest clear turbid halo zone of $14 \mathrm{~mm}$ diameter of violacein inhibition was recorded for the black cardamom and 1,8-cineole at the concentration of $2 \mathrm{mg} /$ disc. The highest diameter of violacein inhibition was noted for the green cardamom about $28 \mathrm{~mm}$ and $16 \mathrm{~mm}$ with the Ethiopian cardamom essential oil (Figure 3). 

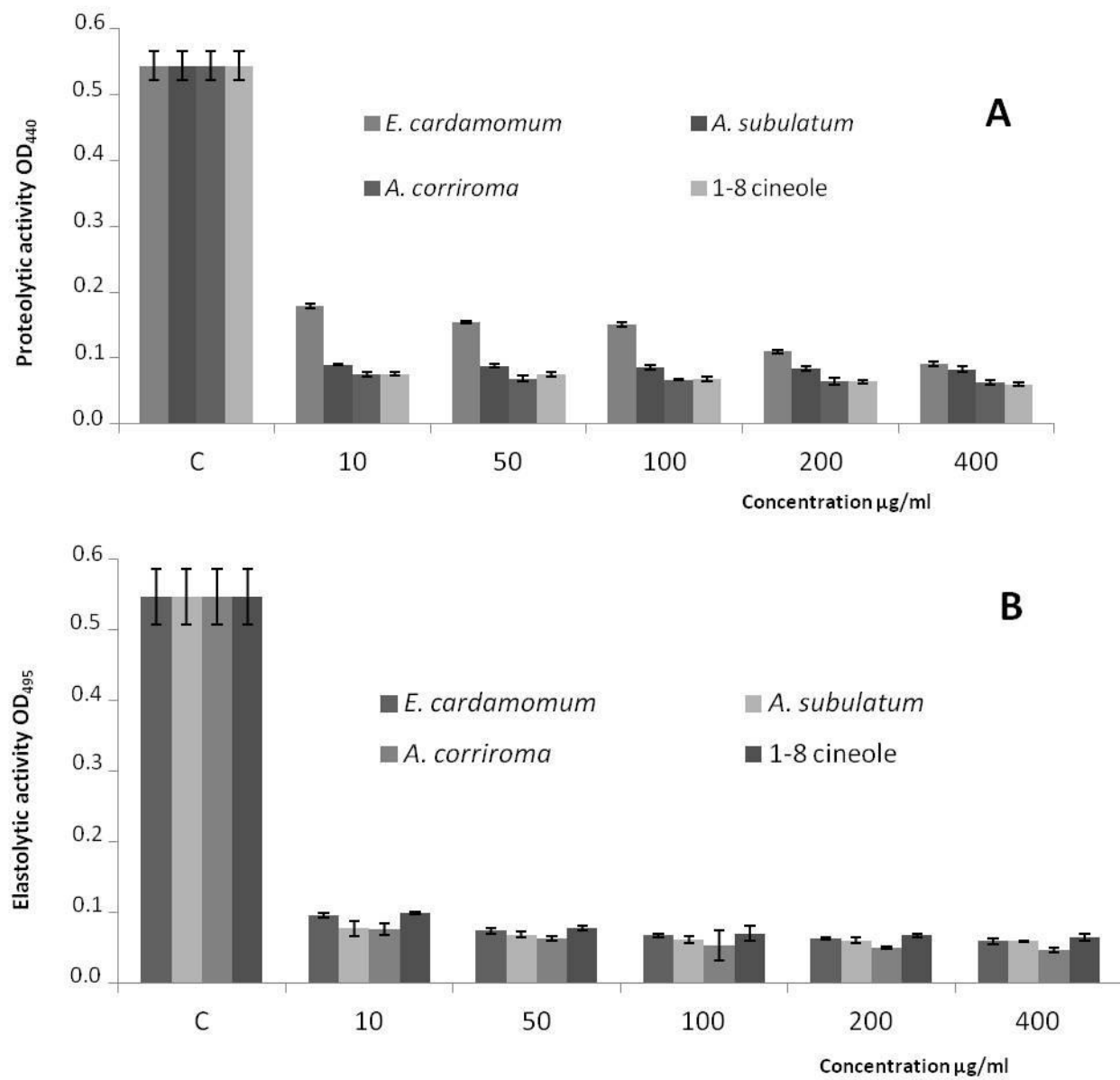

Figure 2. The effect of the tested essential oils and 1,8-cineole on Quorum Sensing-regulated proteolytic (A) and Quorum Sensing-regulated elastolytic (B) activities in P. aeruginosa PAO1. Values are expressed as mean $\pm \mathrm{SD}$.

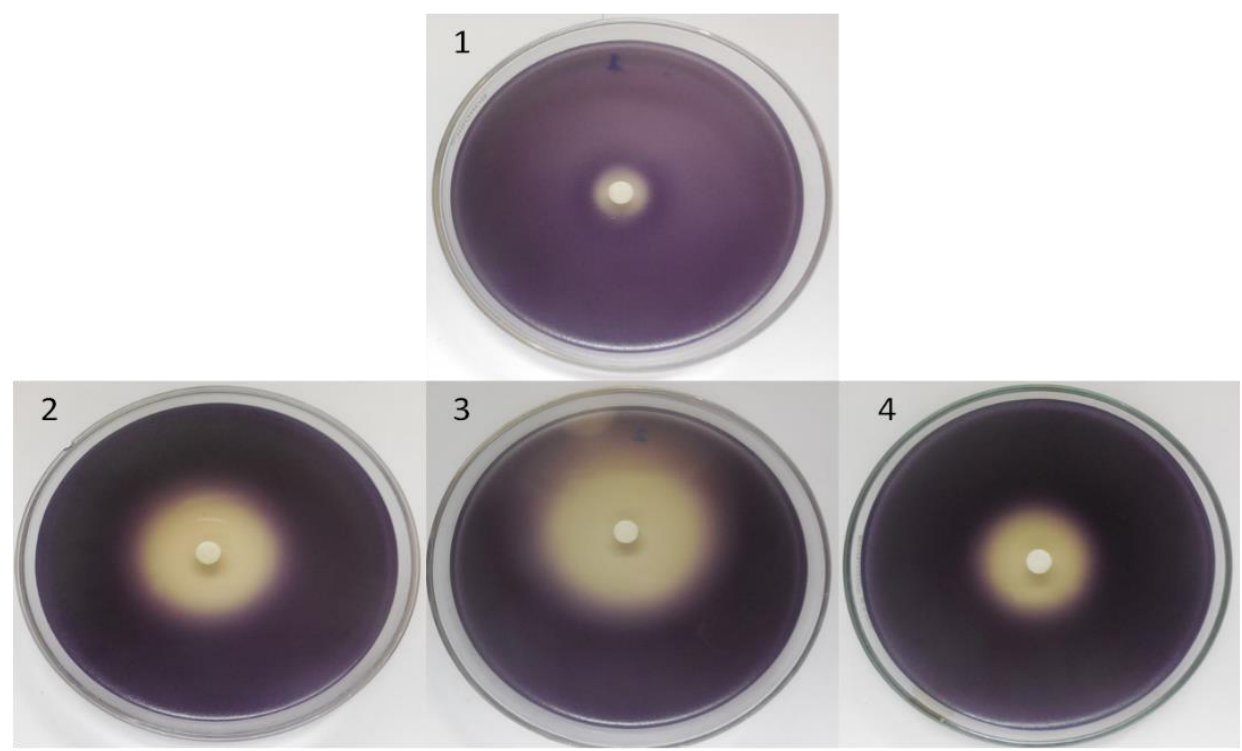

Figure 3. Anti-QS activity of 1,8-cineole (1) Ethiopian cardamom oil (2) green cardamom oil (3) and black cardamom oil (4) as demonstrated by the inhibition of C6-Acyl Homoserine Lactone-mediated violacein production in C. violaceum 026 starter strain. 


\subsection{Phytotoxic Activity}

In this study, the three essential oils were evaluated for their activity against germination and radicle elongation of radish (Raphanus sativus L.), garden cress (Lepidium sativum L.), and lettuce (Lactuca sativa L.).

Doses of $2.5,1.25$, and $0.625 \mu \mathrm{g} / \mathrm{mL}$ of $A$. corrorima essential oil inhibited significantly the germination of radish, but not influenced the germination of the other species. Instead, A. subulatum and E. cardamomum essential oils not influenced the germination of the species considered (Table 5). None of three oils, instead, seem to be effective against radicle elongation of all these species (data no shown).

Table 5. Phytotoxic activity of the three essential oils of A. corriroma, A. subulatum, and E. cardamomum against germination of $R$. sativus, L. sativum, and L. sativa seeds. Data expressed in number of seeds germinated $\pm \mathrm{SD}$ after $120 \mathrm{~h}$ of sowing. ${ }^{* *} p<0.01{ }^{*} p<0.05$.

\begin{tabular}{|c|c|c|c|}
\hline \multicolumn{4}{|c|}{ Raphanus sativus Germinated Seeds } \\
\hline Doses $(\mu \mathrm{g} / \mathrm{mL})$ & A. corriroma & A. subulatum & E. cardamomum \\
\hline Control & $5.70 \pm 1.50$ & $5.00 \pm 1.70$ & $7.30 \pm 1.20$ \\
\hline 0.062 & $7.30 \pm 1.20$ & $4.70 \pm 1.20$ & $4.00 \pm 0.00$ \\
\hline 0.125 & $5.30 \pm 2.30$ & $7.00 \pm 1.00$ & $4.70 \pm 2.50$ \\
\hline 0.250 & $4.33 \pm 2.08$ & $6.00 \pm 1.00$ & $5.67 \pm 1.53$ \\
\hline 0.625 & $5.00 \pm 1.00 *$ & $6.33 \pm 2.08$ & $5.33 \pm 0.58$ \\
\hline 1.25 & $5.00 \pm 1.00 *$ & $5.67 \pm 1.53$ & $5.67 \pm 2.89$ \\
\hline 2.5 & $3.67 \pm 0.58^{* *}$ & $5.00 \pm 1.73$ & $6.67 \pm 2.52$ \\
\hline \multicolumn{4}{|c|}{ Lactuca sativa Germinated Seeds } \\
\hline Doses $(\mu \mathrm{g} / \mathrm{mL})$ & A. corriroma & A. subulatum & E. cardamomum \\
\hline Control & $8.70 \pm 0.60$ & $9.30 \pm 1.20$ & $6.70 \pm 0.60$ \\
\hline 0.062 & $8.30 \pm 0.60$ & $8.70 \pm 1.50$ & $8.00 \pm 1.00$ \\
\hline 0.125 & $8.70 \pm 0.60$ & $8.70 \pm 0.60$ & $9.70 \pm 0.60$ \\
\hline 0.250 & $8.00 \pm 1.00$ & $8.70 \pm 1.50$ & $9.00 \pm 1.00$ \\
\hline 0.625 & $9.00 \pm 1.00$ & $8.70 \pm 1.20$ & $8.30 \pm 2.10$ \\
\hline 1.25 & $9.00 \pm 0.00$ & $8.70 \pm 1.50$ & $8.30 \pm 0.60$ \\
\hline 2.5 & $8.00 \pm 1.00$ & $8.30 \pm 1.50$ & $8.70 \pm 0.60$ \\
\hline \multicolumn{4}{|c|}{ Lepidium sativum Germinated Seeds } \\
\hline Doses $(\mu \mathrm{g} / \mathrm{mL})$ & A. corriroma & A. subulatum & E. cardamomum \\
\hline Control & $3.30 \pm 0.60$ & $6.3 \pm 1.50$ & $4.30 \pm 1.20$ \\
\hline 0.062 & $4.70 \pm 2.50$ & $6.00 \pm 1.70$ & $5.30 \pm 1.20$ \\
\hline 0.125 & $2.30 \pm 1.50$ & $5.30 \pm 1.50$ & $6.00 \pm 2.60$ \\
\hline 0.250 & $3.67 \pm 2.50$ & $4.67 \pm 0.60$ & $6.00 \pm 2.00$ \\
\hline 0.625 & $2.30 \pm 0.60$ & $6.70 \pm 1.20$ & $4.00 \pm 3.50$ \\
\hline 1.25 & $4.00 \pm 2.00$ & $3.70 \pm 2.10$ & $3.30 \pm 2.10$ \\
\hline 2.5 & $3.30 \pm 1.50$ & $4.70 \pm 2.30$ & $4.00 \pm 1.70$ \\
\hline
\end{tabular}

\section{Discussion}

Our results showed that the tested A. subulatum essential oil was characterized by high proportion of monoterpenes (84.6) dominated by the 1,8-cineole and geraniol. Really, in all essential oils tested, 1,8-cineole was the dominant compound found with a percentage varying from 41.7 to $55.4 \%$. The obtained results were in agreement with those reported in the literature. In fact, in a previous work, we reported that the green cardamom was particularly rich in oxygenated monoterpenes $(88.7 \%)$ with a dominance of $\alpha$-terpinyl acetate (45.6\%), 1,8-cineole (26\%). Additionally, several reports have shown that the basic green cardamom aroma from different geographic origin is a combination of 1,8-cineole and $\alpha$-terpinyl acetate with different percentages [25]. In fact, Leela and coworkers [28] studied the content and the chemical composition of seven cardamom genotypes from 
India at different maturity levels (stage of capsule development) and reported that $\alpha$-terpinyl acetate and 1,8-cineole were always the main components. In 2006, Hymete and colleagues [29] reported that the seed oil of Aframomum corrorima from Ethiopia was particularly rich on the monoterpenes 1,8-cineole (44.3\%) and sabinene (17.3\%), whereas the sesquiterpenic compounds (E)-nerolidol (17.2\%), $\beta$-caryophyllene $(9.7 \%)$ and caryophyllene oxide $(6.9 \%)$ dominated the composition of the husk oil. Eyob and colleagues [18] conducted an ethnobotanical survey in the southern regions of Ethiopia on the three major korarima growing wild including Gamo Gofa, Debub Omo and Kaffa. They identified 38 and 52 compounds, respectively in leaf and rhizome essential oils. The major component of the oil of the leaf was $\beta$-caryophyllene $(60.7 \%)$. The rhizome oil was dominated by $\gamma$-terpinene $(21.8 \%)$ and $\beta$-pinene (17.6\%). Similar results have been reported by Baser and Kürkçüoglu [30]. Kumar and co-workers [19] reported the chemical composition of the hydrodistilled essential oil obtained from the fruits of $A$. subulatum grown in northeast region of Sikkim (India) by using the capillary GC and GC-MS techniques. They reported that the hydrodistillated oil was dominated by 1,8-cineole (65.39\%), $\alpha$-terpineol (10.15\%), $\beta$-pinene (7.23\%). In 2013, Joshi and colleagues [31] reported the GC-MS profile of the essential oils from the different locations in India. The oils collected showed qualitative and quantitative differences in composition with a dominance of oxygenated monoterpenes (65.31-75.54\%), monoterpene hydrocarbons (10.53-17.12\%), terpene alcohols (15.32-18.80\%), and sesquiterpene hydrocarbons (5.02-9.19\%). The oxygenated monoterpene 1,8-cineole (50.55-60.46\%) represent the major compound in the oils collected from all regions tested.

Our results confirmed the antimicrobial activity of the three essential oils tested independently of the microorganisms used: in fact, Grădinaru and colleagues [32] reported anti-Staphylococcus aureus ATCC 25923 activity of the green cardamom oil at a concentration of $6.25 \mathrm{mg} / \mathrm{mL}$. While, the methicillin-resistant clinical isolates of $S$. aureus (MRSA) were most susceptible to 1,8-cineole $(\mathrm{MIC}=1.25 \mathrm{mg} / \mathrm{mL})$ as compared to the cardamom oil $(\mathrm{MIC}=6.25 \mathrm{mg} / \mathrm{mL})$. Additionally, we have previously reported that the green cardamom essential oil was active against a large panel of Gram-positive bacteria (mean diameter $=21.77 \mathrm{~mm}$ ), cariogenic bacteria (mean diameter $=19.51 \mathrm{~mm}$ ) and fungi (mean diameter $=39.5 \mathrm{~mm}$ ), with MICs values ranging from 0.023 to $0.046 \mathrm{mg} / \mathrm{mL}$ for all bacterial and fungal strains tested [25]. Recently, Teneva and coworkers [33] reported that the green cardamom oil (chemotype $\alpha$-terpinyl acetate $39.03 \%$, eucalyptol $31.53 \%$ ) was active against pathogenic E. coli ATCC 25922, E. coli ATCC 8739, Salmonella sp., S. aureus ATCC 6538P, and P. vulgaris strains with a diameters of inhibition zones between 8 and $10 \mathrm{~mm}$ and MICs values from 60 to >600 ppm. In 2017, Mutlu-Ingok and Karbancioglu-Guler [34] reported that the green cardamom oil (chemotype $\alpha$-terpinyl acetate $43.4 \%$, eucalyptol $29.2 \%$ ) was active against Campylobacter jejuni and Campylobacter coli with a diameter of growth inhibition zone ranging from $24.75 \mathrm{~mm}$ to 25.58 , respectively. The MICs and MBCs values were low for the two Campylobacter strains tested $(0.025 \mu \mathrm{L} / \mathrm{mL})$.

For the black cardamom oil, Satyal and coworkers [35] reported an antifungal activity of the black cardamom oil against the fungus Aspergillus niger with a MIC value about $313 \mu \mathrm{g} / \mathrm{mL}$, but also a good antibacterial activity against B. cereus, S. aureus, E. coli, and P. aeruginosa strains (MICs values ranging from 313 to $625 \mu \mathrm{g} / \mathrm{mL}$ ). A good antibacterial activity was also noticed by Naveed and coworkers [36] on multi-drug resistant bacteria with MIC values ranging from $2.83 \mathrm{mg} / \mathrm{mL}$ against E. coli (SS1) strain to $9.4 \mathrm{mg} / \mathrm{mL}$ against the uropathogenic $S$. aureus strain. It have been also previously demonstrated that the black cardamom oil extracted from whole fruits exhibited good results against B. pumilis, B. subtilis, M. luteus, S. aureus, S. epidermidis, P. aeruginosa, E. coli, C. albicans, A. niger and S. cerevisiae strains [37]. The diameter of inhibition zone ranged from $15 \mathrm{~mm}$ (S. cerevisiae) to $20 \mathrm{~mm}$ (B. pumilis and S. epidermidis).

The volatile oil extracted from the fruits of Ethiopian cardamom showed promising anti-C. albicans ATCC 90028 and anti-S. aureus DSM 346 activity, with a diameter of inhibition zone about $35 \mathrm{~mm}$ and $25 \mathrm{~mm}$, respectively (Bacha et al., 2016) [9]. They also showed an antimicrobial activity against several Gram-positive and negative bacteria including E. coli K12 DSM 498, B. cereus ATCC 10987, B. cereus, 
and P. aeruginosa DSM 1117 ones. The MICs values ranged from $12.5 \mathrm{mg} / \mathrm{mL}$ (E. coli K12 DSM 498) to $>25 \mathrm{mg} / \mathrm{mL}$ (P. aeruginosa DSM 1117).

The three essential oils tested exhibited pronounced antimicrobial activity against Gram-positive and Gram-negative bacteria, with the highest diameter of growth inhibition zone recorded for M. luteus NCIMB $8166(41.33 \mathrm{~mm})$ and S. aureus ATCC $6816(32.67 \mathrm{~mm})$ by the green cardamom oil. The Gram-positive bacterium, B. cereus was the most sensitive bacteria to the black cardamom oil $(35.67 \mathrm{~mm})$. This can be explained to the difference in the structure and composition of the cell wall of bacteria belonging to two groups and the different mechanism of action of the various components in each essential oil tested [38]. Using the two biomonitor strains C. violaceum and $P$. aeruginosa PAO1, we founded that all tested essential oils and their main component (1,8-cineole) attenuated the expression of the tested QS-controlled virulence factors (violacein pigment production, elastase and protease production, and motility) in a dose dependent manner. Previous reports have shown that the essential oil extracted by hydrodistillation from the green cardamom (chemotype $\alpha$-terpinyl acetate/1,8-cineole) had anti-QS properties against the sensor plasmid pJBA132 (E. coli strain) with a percentage of inhibition about $31 \%$ after $24 \mathrm{~h}$ of exposure, and a weak activity using the long-chain sensor plasmid pRK-C12 in Pseudomonas putida strain (inhibition 21-22\%). This result indicated that the chemical compounds founded in the green cardamom oil can compete with C6-HSL autoinducers molecules [26]. Al-Haidari and colleagues [39] reported that the green cardamom methanolic extract exhibited significant elimination of pyocyanin formation, significantly inhibited twitching and swimming motilities, and biofilm formation in P. aeruginosa PA14 strain. It has been recently demonstrated that Amomum tsao-ko extract exhibited a high biofilm inhibition when tested against S. typhimurium (51.96\%), S. aureus $(47.06 \%)$, and P. aeruginosa $(45.28 \%)$ at $4 \mathrm{mg} / \mathrm{mL}$. The same authors demonstrated that this extract can inhibit the violacein production $(44.59 \%)$ and anti-swarming activity by $4 \mathrm{mg} / \mathrm{mL}$ extract on S. typhimurium and S. aureus [27].

For the phytotoxic activity test, different studies have reported that some essential oils and their components are potent inhibitors of seed germination and retard plant growth [40]. Germination and seedling growth bioassays are important preliminary screening methods to determine phytotoxic potential of plant extracts and compounds [41]. E. cardamomum, A. corriroma and A. subulatum essentials oils have been recognized for their wide range of physiological and pharmacological properties but no studies were carried out on their phytotoxic activities. The difference in phytotoxic activity of the oils could be attribuited to their chemical composition. A. corrorima essential oil composition is richer in monoterpene hydrocarbons (71.4\%) than other essential oils studied. Our results corroborate with De Martino and coworkers [42] that showed monoterpenes phytotoxic activity as good inhibitory radish seed germination in a dose-dependent way.

In conclusion, this study has determined the chemical structure of Elettaria cardamomum, Aframomum corriroma and Amomum subulatum oils, and showed that these oils were mainly composed of the oxygenated monoeterpens, in particular 1,8-cineole. It is evident that the tested oils have effectively reduced/stopped the bacterial and fungal growth as well as the communication of bacterial cells. It is proposed that cardamom oils especially their extracts may have a potential use in clinical settings for microbial infections.

\section{Materials and Methods}

\subsection{Plant Material}

In this work, three varieties of cardamom (fruits/seeds) were purchased from a local market in Jeddah city (KSA) in 2014 including the green cardamom (Elattaria cardamomum L. Manton), Ethiopian cardamom (Aframomum corrorima) and black cardamom (Amomum subulatum). The plants were identified by Pr. Al-Sieni Abdulbasit and voucher specimens were deposited in the CERTE (Technopark of Borj Cedria, Tunisia). One hundred grams of plant seeds were distilled for three hours with distilled 
water $(500 \mathrm{~mL})$ using a Clevenger-type apparatus [43]. The obtained essential oil was refrigerated in sealed glass vials at $4{ }^{\circ} \mathrm{C}$ until analysis.

\subsection{GC-EIMS Analysis and Identification of the Components}

Gas chromatography-electron ionization mass spectrometry GC/EIMS analyses were performed with a Varian CP-3800 gas-chromatograph (Varian, Inc., Palo Alto, CA, USA) equipped with a HP-5 capillary column $(30 \times 0.25 \mathrm{~mm}$; coating thickness $0.25 \mu \mathrm{m})$ and a Varian Saturn 2000 ion trap mass detector (Varian, Inc., CA, USA). Analytical conditions: injector and transfer line temperatures at 220 and $240{ }^{\circ} \mathrm{C}$, respectively; oven temperature was programmed from 60 to $240{ }^{\circ} \mathrm{C}$ at $3^{\circ} \mathrm{C} / \mathrm{min}$; carrier gas helium at $1 \mathrm{~mL} / \mathrm{min}$; injection of $0.2 \mathrm{~mL}$ (10\% hexane solution); split ratio 1:30. Identification of the constituents was based on comparison of the retention times with those of authentic standards, comparing their Linear Retention Indices relative to the series of $n$-hydrocarbons, and by computer matching against commercial (NIST 98 and ADAMS 95) and home-made library mass spectra built up from pure substances and components of known essential oils and MS literature data [44-47]. Moreover, the molecular weights of all the identified substances were confirmed by GC/CIMS, using methanol as CI ionizing gas [48]. Analysis was also run by using a fused silica HP Innowax polyethylenglycol capillary column ( $50 \mathrm{~m} \times 0.20 \mathrm{~mm}$ i.d., $0.25 \mu \mathrm{m}$ film thickness). In both cases, helium was used as carrier gas $(1.0 \mathrm{~mL} / \mathrm{min})$.

\subsection{Biological Assays}

\subsubsection{Antimicrobial Activities}

The antimicrobial effect of the three volatile oils was tested against 25 food-borne pathogenic bacteria including 25 Gram-positive and Gram-negative bacteria, and against seven yeasts including six Candida spp. strains and one Saccharomyces cerevisiae strain by using the disk diffusion assay $[49,50]$. For the experiments, a loopful of the microorganisms working stocks was enriched on a tube containing $9 \mathrm{~mL}$ of enrichment broth (Mueller Hinton for bacteria and Sabouraud Chloramphenicol for yeast) then incubated at $37^{\circ} \mathrm{C}$ for $18-24 \mathrm{~h}$. The overnight cultures were used for the antimicrobial activity of the essential oils used in this study and the optical density was adjusted at $0.1\left(\mathrm{OD}_{600 \mathrm{~nm}}\right)$. The inoculums were streaked onto $\mathrm{MH}(1 \% \mathrm{NaCl}$ for Vibrio strains) agar plates using a sterile swab. While, the yeast strains were inoculated onto Sabouraud dextrose agar (Biolife, Milan, Italy) and incubated for $18 \mathrm{~h}$ at $37^{\circ} \mathrm{C}$. The yeast cultures were harvested and then suspended in sterile saline $(0.8 \% \mathrm{NaCl})$ and the cell density was adjusted to $10^{7}$ cells $/ \mathrm{mL}\left(\mathrm{OD}_{540}=0.5\right)$. The fungal inoculums were streaked onto fresh Sabouraud dextrose agar plates using a sterile swab.

A sterile filter discs (diameter $6 \mathrm{~mm}$, Biolife, Milan, Italy) were impregnated with $10 \mathrm{mg}$ of each essential oil. Ampicillin $(10 \mathrm{mg} / \mathrm{mL})$ was used in this study as positive controls for all bacterial strains tested. The dishes were incubated at $37^{\circ} \mathrm{C}$ for $18-24 \mathrm{~h}$. The diameter of the zones of inhibition around each of the disks was taken as measure of the antimicrobial activity. Each experiment was carried out in triplicate and the mean diameter of the inhibition zone was recorded.

\subsubsection{Microdilution Method for the Determination of the MIC, MBC/MFC}

The minimal inhibition concentration (MIC) and the minimal bactericidal concentration (MBC) were determined for all bacteria tested in this study as previously described [51,52]. The minimal inhibition concentration (MIC) and the minimal fungicidal concentration (MFC) were determined for all Candida strains as described by Noumi and coworkers [7].

The inocula of the bacterial and fungal strains were prepared from $12 \mathrm{~h}$ broth cultures and suspensions were adjusted to $10^{7} \mathrm{UFC} / \mathrm{mL}$. The essential oils dissolved in $10 \%$ dimethylsulfoxide (DMSO), were first diluted to the highest concentration $(100 \mathrm{mg} / \mathrm{mL})$ to be tested, and $200 \mu \mathrm{L}$ of the essential oils stock solutions were serial twofold diluted in a decreasing concentration range in the 96 well-plate. All 96-well plates were prepared by dispensing into each well $195 \mu \mathrm{L}$ of the correspondent 
broth and $5 \mu \mathrm{L}$ of the bacterial/fungal inocula. The last well containing $195 \mu \mathrm{L}$ of nutrient broth without essential oil and $5 \mu \mathrm{L}$ of the inocula on each strip was used as the negative control. The final volume in each well was $200 \mu \mathrm{L}$. The plates were incubated at $37^{\circ} \mathrm{C}$ for $18-24 \mathrm{~h}$.

The MIC value was determined as the lowest concentration of the sample that did not permit any visible growth of the tested microorganism after incubation. The MBC/MFC values were interpreted as the highest dilution (lowest concentration) of the sample, which showed clear fluid with no development of turbidity and without visible growth. All tests were performed in triplicate.

\subsection{Anti-Quorum Sensing Activities of the Essential Oils}

The anti-quorum sensing activities of the tested essential oils and their main component 1,8-cineole were tested by using three reporter strains Pseudomonas aeruginosa PAO1 and the mutant strain Chromobacterium violaceum CV026. The P. aeruginosa PAO1 strain was incubated at $37^{\circ} \mathrm{C}$ for $24 \mathrm{~h}$. While, the mini-Tn5 mutant $C$. violaceum 026 strains that produces violacein pigment only in the presence of exogenous C6-AHL was grown in Luria-Bertani broth medium at $32{ }^{\circ} \mathrm{C}$.

\subsubsection{Effect on P. aeruginosa PAO1 Virulence Factors}

The following QS-controlled virulence factors in P. aeruginosa PAO1 (swarming, elastolytic, and proteolytic activities) were tested as previously described $[53,54]$.

The effect of the tested oils and 1,8-cineole on the swarming activity in P. aeruginosa PAO1 strain was performed in Luria Bertani semisolid medium (Biorad, France) prepared at $0.5 \%$ agar and supplemented with different oils concentrations ranging from 10 to $400 \mu \mathrm{g} / \mathrm{mL}$. The Petri dishes plates inoculated with P. aeruginosa PAO1 were incubated for $24 \mathrm{~h}$ at $37{ }^{\circ} \mathrm{C}$ and the extent of swarming was determined by measuring the swarming diameter using a $1 \mathrm{~cm}$ flat ruler.

For elastolytic activity, P. aeruginosa PAO1 was grown in LB broth medium supplemented with different concentrations of essential oils and 1,8-cineole and incubated for $16 \mathrm{~h}$ at $37^{\circ} \mathrm{C}$. Then, $100 \mu \mathrm{L}$ of the culture supernatant was added to $900 \mathrm{~mL}$ elastin congo red (ECR, Sigma-Aldrich S.r.l. Milan, Italy) buffer (100 mM Tris, 1 mM CaCl , pH 7.5) containing $20 \mathrm{mg}$ ECR (Sigma-Aldrich S.r.l. Milan, Italy). The eppendorf tubes were incubated for $3 \mathrm{~h}$ at $37^{\circ} \mathrm{C}$. The insoluble ECR was removed by centrifugation and the absorbance of the supernatant was estimated spectrophotometrically at $\mathrm{OD}_{495}$ (UV-1800, Shimadzu, Japan).

For proteolytic activity, $100 \mu \mathrm{L}$ from the culture supernatant, obtained as mentioned above, was added to $900 \mathrm{~mL}$ ECR buffer containing $3 \mathrm{mg}$ azocasein (Sigma-Aldrich S.r.l. Milan, Italy) and incubated for $30 \mathrm{~min}$ at $37^{\circ} \mathrm{C}$. Then, $100 \mu \mathrm{L}$ of trichloroacetic acid $(10 \%, v / v)$ was added to all reaction tubes. After $30 \mathrm{~min}$, the tubes were centrifuged and absorbance of the supernatant was measured by reading spectrophotometrically at $\mathrm{OD}_{440}$ (UV-1800, Shimadzu, Kyoto, Japan).

\subsubsection{Effect on Violacein Production}

Inhibition of violacein production in the presence of tested essential oils and their major component (1,8-cineole) was tested according the method described by McClean and colleagues [55]. For this, two microlitres of essential oil or 1,8-cineole $(2 \mathrm{mg} / \mathrm{disc})$ were loaded to the sterile disks and placed on the surface of CV026 inoculated LB agar plates supplemented with $50 \mu \mathrm{L}$ of $1 \mu \mathrm{g} / \mathrm{mL}$ of C6-HSL. The plates were incubated upright at $32{ }^{\circ} \mathrm{C}$ for $24 \mathrm{~h}$ and zone of inhibition of QS was detected by the presence of colourless but viable cells around the disks and the zone of growth inhibition was also recorded.

\subsection{Phytotoxic Activity of the Essential Oils}

The phytotoxic activity was evaluated on germination and root elongation of three different plant species: R. sativus cv "Saxa" (radish), L. sativum (garden cress) and L. sativa (lettuce). These seeds are well known from the histological point of view and usually they are used in assays of phytotoxicity because of their easy germinability. The seeds of $R$. sativus and L. sativum were purchased from Blumen 
group srl (Piacenza, Italy), the seeds of garden cress from Euroselect (Bari). The seeds were surface sterilized in $95 \%$ ethanol for $15 \mathrm{~s}$ and sown in Petri dishes $(\varnothing=90 \mathrm{~mm})$, containing five layers of Whatman filter paper, impregnated with distilled water $(7 \mathrm{~mL}$, control) or the tested solution of the essential oil $(7 \mathrm{~mL})$, at the different doses. The germination conditions were $20 \pm 1{ }^{\circ} \mathrm{C}$, with natural photoperiod. The essential oils, in water-acetone mixture (99.5:0.5), were assayed at the doses of 2.5, $1.25,0.625,0.25,0.125$ and $0.062 \mu \mathrm{g} / \mathrm{mL}$ Controls performed with water-acetone mixture alone showed no appreciable differences in comparison to controls in water alone. Seed germination was observed directly in Petri dishes every $24 \mathrm{~h}$. A seed was considered germinated when the protrusion of the root became evident [56]. After $120 \mathrm{~h}$ (on the fifth day), the effects on radicle elongation were measured in $\mathrm{cm}$. Each determination was repeated three times, using Petri dishes containing 10 seeds each. Data are expressed as the mean \pm SD for both germination and radicle elongation [57].

\subsection{Statistical Analysis}

All data were expressed as Means \pm Standard Deviation (S.D.). Each analysis was performed using the SPSS 16.0 statistics package for Windows (SPSS Inc., Chicago, IL, USA). The differences in mean were calculated using the Duncan's multiple range tests for means with $95 \%$ confidence limit $(p=0.05)$. A principal component analysis (PCA) and cluster analysis (CA) were performed in order to discriminate between the three cardamom varieties on the basis of their essential oil composition. All analyses were performed by the "Statistica v 5.1" software (Statsoft. Inc., EEUU).

Author Contributions: E.N., M.S., M.M.A., and V.D.F. conceived and designed the experiments; A.A.-s. provided reagents, materials, and analysis tools; M.S. and E.N. carried out microbiological assays; M.S., L.C., L.D.M., E.M. and L.F.S. performed the phytotoxic experiments; K.M. analyzed the data. All authors discussed the data obtained and collaborated in drafting the manuscript.

Funding: The study was funded by The University of Salerno, FARB 2015.

Acknowledgments: This work was supported by The Tunisian High Ministry of High Education and Research.

Conflicts of Interest: The authors declare no conflict of interest.

\section{References}

1. Bakkali, F.; Averbeck, S.; Averbeck, D.; Idaomar, M. Biological effects of essential oils-A review. Food Chem. Toxicol. 2008, 46, 446-475. [CrossRef] [PubMed]

2. Nazzaro, F.; Fratianni, F.; Coppola, R.; Feo, V. Essential Oils and Antifungal Activity. Pharmaceuticals 2017, 210, 86. [CrossRef] [PubMed]

3. De Martino, L.; Nazzaro, F.; Mancini, E.; De Feo, V. Essential Oils from Mediterranean aromatic Plants. In The Mediterranean Diet: An Evidence-Based Approach; Preedy, V.R., Watson, R.R., Eds.; Elsevier: London, UK, 2015; pp. 649-661.

4. Tsigarida, E.; Skandamis, P.; Nychas, G.J.E. Behaviour of Listeria monocytogenes and autochthonous flora on meat stored under aerobic, vacuum and modified atmosphere packaging conditions with or without the presence of oregano essential oil at $5{ }^{\circ} \mathrm{C}$. J. Appl. Microbiol. 2000, 89, 901-909. [CrossRef] [PubMed]

5. Wu, H.; Moser, C.; Wang, H.Z.; Hoiby, N.; Song, Z.J. Strategies for combating bacterial biofilm infections. Int. J. Oral. Sci. 2014, 7, 1-7. [CrossRef] [PubMed]

6. Ciprandi, A.; da Silva, W.M.; Santos, A.V.; de Castro Pimenta, A.M.; Carepo, M.S.; Schneider, M.P.; Azevedo, V.; Silva, A. Chromobacterium violaceum: Important insights for virulence and biotechnological potential by exoproteomic studies. Curr. Microbiol. 2013, 67, 100-106. [CrossRef] [PubMed]

7. Noumi, E.; Snoussi, M.; Merghni, A.; Nazzaro, F.; Quindós, G.; Akdamar, G.; Mastouri, M.; Al-Sieni, A.; Ceylan, O. Phytochemical composition, anti-biofilm and anti-quorum sensing potential of fruit, stem and leaves of Salvadora persica L. methanolic extracts. Microb. Pathog. 2017, 109, 169-176. [CrossRef] [PubMed]

8. Ruimy, R.; Andremont, A. Quorum sensing in Pseudomonas aeruginosa: Molecular mechanism, clinical impact, and inhibition. Réanimation 2004, 13, 176-184. [CrossRef] 
9. Bacha, K.; Tariku, Y.; Gebreyesus, F.; Zerihun, S.; Mohammed, A.; Weiland-Bräuer, N.; Schmitz, R.A.; Mulat, M. Antimicrobial and antiquorum Sensing activities of selected medicinal plants of Ethiopia: Implication for development of potent antimicrobial agents. BMC Microbiol. 2016, 16, 139-147. [CrossRef] [PubMed]

10. Merghni, A.; Noumi, E.; Hadded, O.; Dridi, N.; Panwar, H.; Ceylan, O.; Mastouri, M.; Snoussi, M. Assessment of the antibiofilm and antiquorum sensing activities of Eucalyptus globulus essential oil and its main component 1,8-cineole against methicillin-resistant Staphylococcus aureus strains. Microb. Pathog. 2018, 118, 74-80. [CrossRef] [PubMed]

11. Nazzaro, F.; Fratianni, F.; Coppola, R. Quorum Sensing and Phytochemicals. Int. J. Mol. Sci. 2013, 14, 12607-12619. [CrossRef] [PubMed]

12. Ta, C.A.; Arnason, J.T. Mini Review of Phytochemicals and Plant Taxa with Activity as Microbial Biofilm and Quorum Sensing Inhibitors. Molecules 2016, 21, 29. [CrossRef] [PubMed]

13. Ravindran, P.N.; Shylaja, M.; Babu, K.N. False cardamoms. Med. Aromat. Plants 2002, 30, 330-340.

14. Husain, S.S.; Ali, M. Analysis of volatile oil of the fruits of Elettaria cardamomum (L.) Maton and its antimicrobial activity. World J. Pharm. Pharm. Sci. 2014, 3, 1798-1808.

15. Savan, E.K.; Kucukbay, F.Z. Essential oil composition of Elettaria cardamomum Maton. J. Appl. Biol. Sci. 2013, 7, 42-45.

16. Gilani, S.R.; Shahid, I.; Javed, M.; Mehmud, S.; Ahme, R. Antimicrobial activities and physico-chemical properties of the essential oil from Amomum subulatum. Int. J. Appl. Chem. 2006, 2, 81-86.

17. Eyob, S.; Appelgren, M.; Rohloff, J.; Tsegaye, A.; Messele, G. Chemical composition of essential oils from fresh plant parts of Korarima (Aframomum corrorima) cultivated in the highland of southern Ethiopia. J. Essent. Oil Res. 2007, 19, 372-375. [CrossRef]

18. Eyob, S.; Appelgren, M.; Rohloff, J.; Tsegaye, A.; Messele, G. Traditional medicinal uses and essential oil composition of leaves and rhizomes of korarima (Aframomum corrorima (Braun) P.C.M. Jansen) from southern Ethiopia. S. Afr. J. Bot. 2008, 74, 181-185. [CrossRef]

19. Kumar, G.; Chauhan, B.; Ali, M. Essential oil Composition of the Fruits of Amomum subulatum Roxb. Am. J. PharmTech Res. 2012, 2, 626-632.

20. Kaskoos, R.A.; Ali, M.; Kapoor, R.; Akhtar, M.M.S.; Mir, S.R. Essential oil composition of the fruits of Eletteria cardamomum. J. Essent. Oil Bear. Plants 2006, 9, 81-84. [CrossRef]

21. Kumar, A.; Tandon, S.; Ahmad, J.; Yadav, A.; Kahol, A.P. Essential oil composition of seed and fruit coat of Elettaria cardamomum from South India. J. Essent. Oil Bear. Plants 2005, 8, 204-207. [CrossRef]

22. Olivero-Verbel, J.; Gonzalez-Cervera, T.; Guette-Fernandez, J.; Jaramillo-Colorado, B.; Stashenko, E. Chemical composition and antioxidant activity of essential oils isolated from Colombian plants. Rev. Bras. Farmacog. 2010, 20, 568-574. [CrossRef]

23. Kaskoos, R.A.; Mir, S.R.; Kapoor, R.; Ali, M. Essential oil composition of the fruits of Amomum subulatum Roxb. J. Essent. Oil Bear. Plants 2008, 11, 184-187. [CrossRef]

24. Kaushik, P.; Goyal, P.; Chauhan, A.; Chauhan, G. In Vitro evaluation of antimicrobial potential of dry fruit extracts of Elettaria cardamomum Maton (Chhot Elaichi). Iran J. Pharm. Res. 2010, 9, 287-292. [PubMed]

25. Snoussi, M.; Noumi, E.; Dehmani, A.; Flamini, G.; Aouni, M.; Al-sieni, M.; Al-sieni, A. Chemical Composition and Antimicrobial Activities of Elettaria cardamomum L. (Manton) Essential Oil: A High Activity against a Wide Range of Food Borne and Medically Important Bacteria and Fungi. J. Chem. Biol. Phys. Sci. 2015, 6, 248-259.

26. Jaramillo-Colorado, B.; Olivero-Verbel, J.; Stashenko, E.E.; Wagner-Döbler, I.; Kunze, B. Anti-quorum sensing activity of essential oils from Colombian plants. Nat. Prod. Res. 2012, 26, 1075-1086. [CrossRef] [PubMed]

27. Rahman, M.R.T.; Lou, Z.X.; Yu, F.H.; Wang, P.; Wang, H.X. Anti-quorum sensing and anti-biofilm activity of Amomum tsaoko (Amommum tsao-ko Crevost et Lemarie) on foodborne pathogens. Saudi J. Biol. Sci. 2017, 24, 324-330. [CrossRef] [PubMed]

28. Leela, N.K.; Prasath, D.; Venugopal, M.N. Essential oil composition of selected cardamom genotypes at different maturity levels. Indian J. Hortic. 2008, 65, 366-369.

29. Hymete, A.; Rohloff, J.; Iversen, T.-H. Essential oil from seeds and husks of Aframomum corrorima from Ethiopia. Flavour Fragr. J. 2006, 21, 642-644. [CrossRef]

30. Baser, K.H.C.; Kürkçüoglu, M. The Essential Oils of Aframomum corrorima (Braun) Jansen and A. angustifolium K. Schum. from Africa. J. Essent. Oil Res. 2001, 13, 208-209. [CrossRef] 
31. Joshi, R.; Sharma, P.; Sharma, V.; Prasad, R.; Sud, R.K.; Gulati, A. Analysis of the essential oil of large cardamom (Amomum subulatum Roxb.) growing in different agro-climatic zones of Himachal Pradesh, India. J. Sci. Food Agric. 2013, 93, 1303-1309. [CrossRef] [PubMed]

32. Grădinaru, A.C.; Aprotosoaie, A.C.; Trifan, A.; Șpac, A.; Brebu, M.; Miron, A. Interactions between cardamom essential oil and conventional antibiotics against Staphylococcus aureus clinical isolates. Farmacia 2014, 62, 1214-1222.

33. Teneva, D.; Denkova, Z.; Goranov, B.; Denkova, R.; Kostov, G.; Atanasova, T.; Merdzhanov, P. Chemical composition and antimicrobial activity of essential oils from black pepper, cumin, coriander and cardamom against some pathogenic microorganisms. Acta Univ. Cibiniensis Ser. E 2016, 2, 39-52. [CrossRef]

34. Mutlu-Ingok, A.; Karbancioglu-Guler, F. Cardamom, cumin, and dill weed essential oils: Chemical compositions, antimicrobial activities, and mechanisms of action against Campylobacter spp. Molecules 2017, 22, 1191. [CrossRef] [PubMed]

35. Satyal, P.; Dosoky, N.S.; Kincer, B.L.; Setzer, W.N. Chemical compositions and biological activities of Amomum subulatum essential oils from Nepal. Nat. Prod. Commun. 2012, 7, 1233-1236. [PubMed]

36. Naveed, R.; Hussain, I.; Tawab, A.; Tariq, M.; Rahman, M.; Hameed, S.; Mahmood, M.S.; Siddique, A.B.; Iqbal, M. Antimicrobial activity of the bioactive components of essential oils from Pakistani spices against Salmonella and other multi-drug resistant bacteria. BMC Complement. Altern. Med. 2013, 13, 265-274. [CrossRef] [PubMed]

37. Agnihotri, S.; Wakode, S. Antimicrobial activity of essential oil and various extracts of fruits of greater cardamom. Indian J. Pharm. Sci. 2010, 72, 657-659. [CrossRef] [PubMed]

38. Karaman, I.; Sahin, F.; Gulluce, M.; Ogutcu, H.; Sengul, M.; Adiguzel, A. Antimicrobial activity of aqueous and methanol extracts of Juniperus oxycedrus L. J. Ethnopharmacol. 2003, 85, 231-235. [CrossRef]

39. Al-Haidari, R.A.; Shaaban, M.I.; Ibrahim, S.R.M.; Mohamed, G.A. Anti-quorum sensing activity of some medicinal plants. Afr. J. Tradit. Complement. Altern. Med. 2016, 13, 67-71. [PubMed]

40. Buchbauer, G. Biological activities of essential oils. In Handbook of Essential Oils: Science, Technology, and Applications; Baser, K.H.C., Buchbauer, G., Eds.; CRC Press: Boca Raton, FL, USA, 2010; pp. 235-280.

41. Choi, H.; Sowndhararajan, K.; Cho, N.; Hwang, K.; Koo, S.; Kim, S. Evaluation of Herbicidal Potential of Essential Oils and their components under in vitro and green house experiments. Weed Turf. Sci. 2015, 4, 321-329. [CrossRef]

42. De Martino, L.; Mancini, E.; Rolim de Almeida, L.F.; De Feo, V. The antigerminative activity of twenty-seven monoterpenes. Molecules 2010, 15, 6630-6637. [CrossRef] [PubMed]

43. European Pharmacopoeia, 5th ed.; Council of Europe: Strasbourg, France, 2004; Volume 1, pp. 217-218.

44. Jennings, W.; Shibamoto, T. Qualitative Analysis of Flavour and Fragrance Volatiles by Glass Capillary Gas Chromatography; Academic Press: New York, NY, USA, 1980.

45. Davies, N.W. Gas chromatographic retention indices of monoterpenes and sesquiterpenes on methyl silicone and Carbowax 20M phases. J. Chromatogr. 1990, 503, 1-24. [CrossRef]

46. Adams, R.P. Identification of Essential Oil Components by Gas Chromatography/Mass Spectroscopy, 4th ed.; Allured Publishing Corporation: Carol Stream, IL, USA, 2007.

47. Goodner, K.L. Practical retention index models of OV-101, DB-1, DB-5, and DB-Wax for flavor and fragrance compounds. LWT Food Sci. Technol. 2008, 41, 951-958. [CrossRef]

48. Wiley Registry of Mass Spectral Data, with NIST Spectral Data CD Rom, 7th ed.; John Wiley \& Sons: New York, NY, USA, 1998.

49. Snoussi, M.; Hajlaoui, H.; Noumi, E.; Usai, D.; Sechi, L.A.; Zanetti, S.; Bakhrouf, A. In vitro anti-Vibrio spp. activity and chemical composition of some Tunisian aromatic plants. World J. Microbiol. Biotechnol. 2008, 24, 3071-3076. [CrossRef]

50. Snoussi, M.; Noumi, E.; Trabelsi, N.; Flamini, G.; Papetti, A.; de Feo, V. Mentha spicata essential oil: Chemical composition, antioxidant and antibacterial activities against planktonic and biofilm cultures of Vibrio spp. strains. Molecules 2015, 20, 14402-14424. [CrossRef] [PubMed]

51. Gulluce, M.; Sahin, F.; Sokmen, M.; Ozer, H.; Daferera, D.; Sokmen, A.; Polissiou, M.; Adiguzel, A.; Ozkan, H. Antimicrobial and antioxidant properties of the essential oils and methanol extract from Mentha longifolia L. ssp. longifolia. Food Chem. 2007, 103, 1449-1456. [CrossRef] 
52. Snuossi, M.; Trabelsi, N.; Taleb, S.-B.; Dehmeni, A.; Flamini, G.; De Feo, V. Laurus nobilis, Zingiber officinale and Anethum graveolens Essential Oils: Composition, Antioxidant and Antibacterial Activities against Bacteria Isolated from Fish and Shellfish. Molecules 2016, 21, 1414. [CrossRef] [PubMed]

53. Vasavi, H.S.; Arun, A.B.; Rekha, P.D. Anti-quorum sensing potential of Adenanthera pavonina. Pharmacogn. Res. 2015, 7, 105-109.

54. Vasavi, H.S.; Arun, A.B.; Rekha, P.D. Anti-quorum sensing activity of flavonoid-rich fraction from Centella asiatica L. against Pseudomonas aeruginosa PAO1. J. Microbiol. Immunol. Infect. 2016, 49, 8-15. [CrossRef] [PubMed]

55. McClean, K.H.; Winson, M.K.; Fish, L.; Taylor, A.; Chhabra, S.R.; Camara, M. Quorum sensing and Chromobacterium violaceum: Exploitation of violacein production and inhibition for the detection of $N$-acylhomoserine lactones. Microbiology 1997, 143, 3703-3711. [CrossRef] [PubMed]

56. Sokal, R.R.; Rohlf, F.J. Biometry, 4th ed.; W.H. Freeman and Company: New York, NY, USA, 2012.

57. Bewley, D.; Black, M. Seeds: Physiology of Development and Germination; Plenum Press: New York, NY, USA, 1985.

Sample Availability: Samples of the essential oils are available from the authors.

(c) 2018 by the authors. Licensee MDPI, Basel, Switzerland. This article is an open access article distributed under the terms and conditions of the Creative Commons Attribution (CC BY) license (http:/ / creativecommons.org/licenses/by/4.0/). 